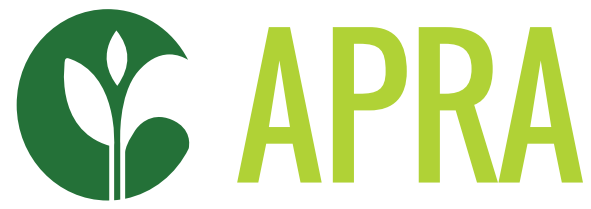

Agricultural Policy Research in Africa

\title{
RICE COMMERCIALISATION, AGRARIAN CHANGE AND LIVELIHOOD TRAJECTORIES: TRANSFORMATIONS ON THE FOGERA PLAIN OF ETHIOPIA
}

Dawit Alemu, John Thompson and Abebaw Assaye 


\section{CONTENTS}

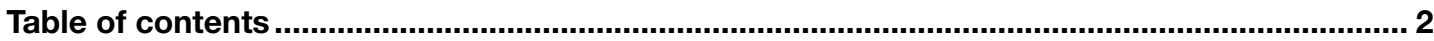

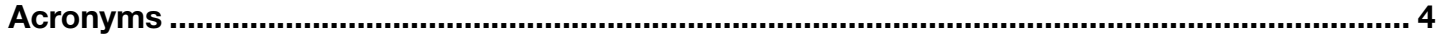

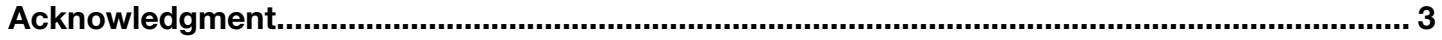

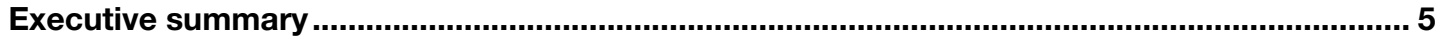

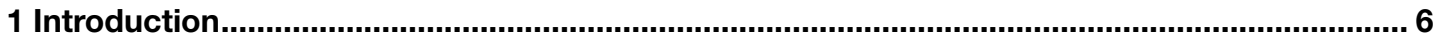

2 Historical trends: the introduction and commercialisation of rice in Ethiopia ........................ 9

2.1 Political economy of agriculture and the introduction of rice ........................................ 9

2.2 Trends in rice production, imports and domestic consumption ...................................... 12

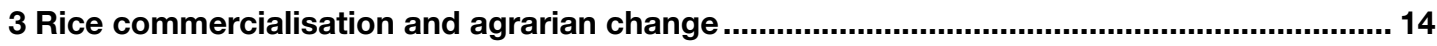

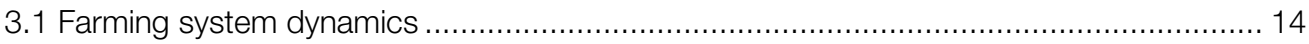

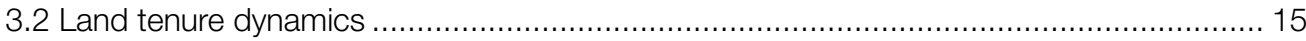

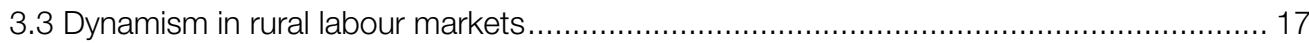

3.4 Changes in the type and use of agricultural technologies ............................................. 18

3.5 Changes in rural markets and rural-urban linkages................................................... 18

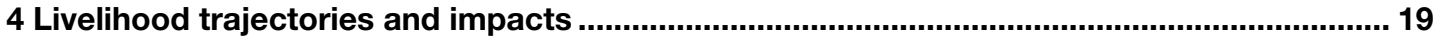

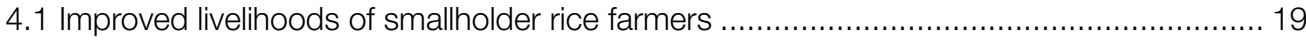

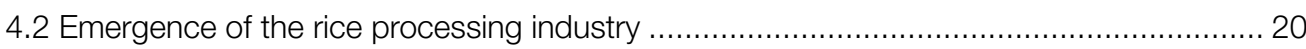

4.3 Expansion of other private businesses and urbanisation .......................................... 21

4.4 Opportunities for youth and women ...................................................................... 22

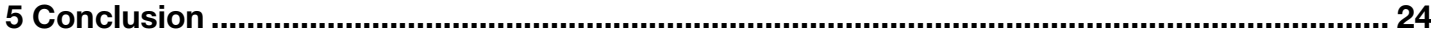

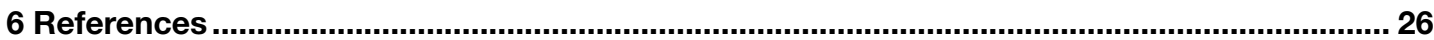

Tables

Table 2.1 Chronology of the introduction of rice and rice sector development in Ethiopia ........ 9

Table 3.1 Trends in water pump ownership in Fogera district (2017-2020) ........................... 15

Table 3.2 Proportion of smallholder rice farmers using hired labour by operation.................. 17

Table 4.1 Expansion of businesses in Wereta.................................................................. 21

\section{Figures}

Figure 2.1 Trends in domestic production, import and consumption, 2008-19 ................... 13

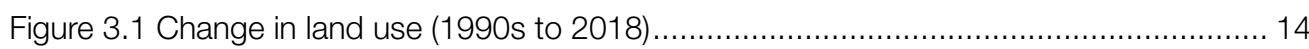

Figure 4.1 Trends in the number of rice processors in Fogera Plain ................................... 20 


\section{ACKNOWLEDGEMENTS}

Dawit Alemu is an agricultural economist serving as a manager of the Bilateral Ethiopian-Netherlands Effort for Food, Income and Trade Partnership in Ethiopia. He is also a member of the Future Agricultures Consortium (FAC) and country lead of the Agricultural Policy Research in Africa (APRA) programme in Ethiopia. John Thompson is a Senior Research Fellow at the Institute of Development Studies (IDS), UK. He serves as the Director of FAC and CEO of APRA. Abebaw Asaye is a Researcher at the National Rice Research and Training Center (NRRTC) of the Ethiopian Institute of Agricultural Research (EIAR) and is a member of APRA in Ethiopia.

This working paper is funded with UK aid from the UK government (Foreign, Commonwealth \& Development Office - FCDO, formerly DFID). The opinions are the authors and do not necessarily reflect the views or policies of IDS or the UK government. 


\section{ACRONYMS}

\begin{tabular}{|c|c|}
\hline AbARC & Abobo Agricultural Research Centre \\
\hline AdARC & Adet Agricultural Research Centre \\
\hline APRA & Agricultural Policy Research in Africa \\
\hline ATVET & Agricultural Technical Vocational Education and Training College \\
\hline CSA & Central Statistical Agency \\
\hline EPRDF & Ethiopian People's Revolutionary Democratic Front \\
\hline ERCA & Ethiopian Revenue and Customs Authority \\
\hline FAC & Future Agricultures Consortium \\
\hline FGD & focus group discussion \\
\hline GARI & Gambella Agricultural Research Institute \\
\hline IAR & Institute of Agricultural Research \\
\hline IRRI & International Rice Research Institute \\
\hline NERICA & New Rice for Africa \\
\hline NGO & non-governmental organisation \\
\hline NRRTC & National Rice Research and Training Centre \\
\hline PARC & Pawe Agricultural Research Centre \\
\hline PDRE & People's Democratic Republic of Ethiopia \\
\hline PSNP & Productive Safety Net Programme \\
\hline R\&D & research and development \\
\hline SAA & Sasakawa Africa Association \\
\hline SNNPR & Southern Nations, Nationalities, and Peoples' Region \\
\hline SSA & Sub-Saharan Africa \\
\hline TVET & Technical Vocational Education and Training College \\
\hline
\end{tabular}




\section{EXECUTIVE SUMMMARY}

Rice was considered a minor crop in Ethiopia, rarely consumed by many households in Sub-Saharan Africa (SSA). In recent decades, however, it has become the most rapidly growing staple food source in the country. This paper presents an historical analysis of rice commercialisation and the observed agrarian changes that have resulted from its introduction and spread in Ethiopia.

Drawing on both primary and secondary data sources, this paper analyses the role of the state, private actors, and development partners in promoting improvements in rice production and value chain upgrading. The paper also examines the impacts of small-scale commercialisation on local livelihoods and rural economies, drawing specific insights from experiences in Fogera Plain, an area which has been transformed from a food-deficit to a food-surplus region following the introduction of rice.

This paper documents the key drivers of transformation of Fogera's rice system:

- Changes in farming systems brought about by considerable change in land use with differentiated results in the lowland and upland rice agroecologies found in the area.

- Increasing economic incentives following the expansion of rice production in waterlogged areas which previously were used mainly for extensive livestock production, and which have brought changes to the land tenure system and led to the emergence of dynamic formal and informal land markets.

- Changes in rural labour and gender relations where the expansion and intensification of rice production in Fogera has been associated with the emergence of a thriving off-farm labour market and an emerging phenomenon of increased participation of female workers in the labour market.

- Changes in the type and use of agricultural technologies where farmers reported an increased use of modern agricultural technologies, such as quality seed of preferred varieties, agro-chemicals (chemical fertiliser, herbicides and pesticides), and irrigation technologies (shallow wells and pumps).
- Changes in rural markets and rural-urban linkages mainly related with the emergence and expansion of rural agricultural product markets, and private rural services (input suppliers, transport providers, processors, etc).

These observed changes in Fogera that have been tracked over the past 40 years include direct and indirect improvements at the level of farming households and other value chain actors in terms of increased income, the spill-over effects related with non-farm investments, and increased demand for both private and public goods and services. This paper concludes by illustrating how these rice-based livelihood trajectories can be scaled up and mainstreamed in the country's agricultural transformation agenda. 


\section{INTRODUCTION}

Historically, rice was viewed as a relatively minor crop in SSA, but it has now become the most rapidly growing staple food source in the region (Seck et al., 2013). This trend has been seen in Ethiopia, which has experienced a considerable increase in rice consumption along with increases both in domestic production and imports over the past several decades. This paper presents an historical analysis of rice commercialisation, the observed agrarian changes that have resulted from its introduction, and its impacts on local livelihoods and rural economies in the country, drawing insights from the experience of the Fogera Plain, a dynamic farming area in Amhara Region to the east of Lake Tana.

There has always been a wide variation in cropping choices made by farmers across Ethiopia, given the country's tremendous agroecological and sociocultural diversity. These patterns changed markedly during the post-World War II era and later as a part of the post-1960s 'Green Revolution' period. Since then, the most significant long-term national trends have seen a steady decline in barley, a highland crop, which moved from the dominant cereal nationally to rank third. Highland Ethiopia's indigenous cereal, teff, expanded its position and surpassed barley as the major crop in the mid-1960s, probably reflecting both urban tastes and cropping specialisation in intense cereal production areas in the highlands. 'The increasing role of maize and rice in the country's crop mix is a more recent phenomenon; a crop that had come to dominate southern Ethiopia and in mid-altitude areas of the north (Watt, 1988; McCann, 2005).

The history of the introduction of rice and maize in Ethiopia, and the associated research and development (R\&D) interventions to support them, follow a similar pattern, except for the difference in their arrival and emergence as important commodities in the country. Maize arrived in Ethiopia around the late seventeenthcentury (Huffnagel, 1961; McCann, 2005), while rice was only introduced at the end of the twentiethcentury, in the 1970s (Alemu et al., 2018).

For most of its history in Ethiopia, maize was grown primarily as a subsistence crop in the mid-altitudes (1,500-2,000m above sea level) in the southern, southcentral, and south-western parts of the country. The production system in the 1960s and for the first quarter of 1970s remained largely at a subsistence level, with yields barely exceeding 1t/ha. However, since the 1980s, maize has become the largest cereal commodity in terms of production, yield and acreage next to teff. This can be attributed to state support, market expansion and farmer preference (Alemu et al., 2014).

A major trend in cropping appears to be the shift to lowland and mid-altitude crops both in terms of national percentages and in specific locations. In the first instance, the expansion of cultivation to marginal lowland areas in the past few generations accounts for the rapid expansion of maize and rice in the national cropping mix. At the same time, maize has expanded because its agronomic characteristics (low labour requirements, short cycle) suited the expansion of coffee cultivation, the need to double-crop on shrinking household plots and demands for off-farm labour. The negative implications of such changes in cropping trends in Ethiopia are not the result of bad decisions by farmers but rather the overall political economic conditions that threatened food security in an era of sustained drought.

Since its introduction in the 1970s, rice has brought diverse opportunities for smallholder farmers, who started cultivating it first as a food security crop, and thereafter as a commercial crop, particularly in waterlogged areas where production of other crops was not suitable. These changes not only increased food security in areas that were once food-deficit regions, but also enhanced market linkages due to increased urban demand which has brought considerable changes in agrarian relations and livelihood options, both on and off-farm.

These rice-based livelihoods have followed several trajectories that have been observed in other parts of Africa (Dorward, et al. 2006, 2009; Chirwa and Dorward, 2016; Shonhe, Scoones and Murimbarimba, 2020; Omotilewa, et al. 2021) by households seeking to improve their well-being by engaging in commercial agriculture through:

1 Teff (Eragrostis tef) is an indigenous multipurpose cereal crop which has a high importance for the Ethiopian diet and culture, but which is low yielding. 
- $\quad$ 'Stepping up' - improving existing agricultural activities by increasing investment in technology, land and/or labour and increasingly engaging in market-based production;

- 'Stepping out' - intensifying, specialising and accumulating assets to diversify and create alternative, non-farm economic activities, including value-addition, agro-processing, etc.; and

- 'Stepping in' - returning to or moving into commercial agriculture from a non-farm base, often by 'investor farmers' seeking to produce mainly for the market.

Households that are constrained in resources (land, labour, capital and other factors of production) are less likely to engage in rice commercialisation. These include households that are:

- $\quad$ 'Hanging in' - maintaining a subsistence level in agriculture, often as net consumers, not surplus producers for the market; and

- 'Dropping out' - moving out of productive agriculture or slipping into destitution due to various short and longer-term shocks and stresses.

Members of the households in these latter categories may serve as a pool of labour for the more commercialised households, providing either shortterm or seasonal labour, particularly during intensive periods of land preparation and weeding or working as labourers for local transporters, processors and merchants in the nearby towns and cities. These options may be particularly important for rural youth, who may be land poor or landless. These households may also require forms of social protection to provide a safety net to support them to cope with the shocks and stresses or to 'graduate' to a trajectory of 'stepping up' (Devereux and Sabates-Wheeler, 2015).

Rice production in Ethiopia is promoted mainly in three niche regions where there were early introductions that subsequently followed different development pathways: Fogera in Amhara Region, Gambella in Gambella Region, and Pawe in Benishangul-Gumuz Region (Asmelash 2014; Alemu et al., 2018). However, with targeted interventions by both federal and regional government agencies and development partners, rice production has expanded into the Maytsebri area in Tigray Region, Assosa in Benishanul Gumoz, Gura Ferda in Southern Nations, Nationalities, and Peoples' Region (SNNPR), Chewaka in Oromia Region, and Gode in Somali Region. Today, over 70 per cent of national rice production comes from the Fogera Plain, though expansion is happening quickly in these other regions (MoA, 2020). Moreover, in recognition of the increased importance of rice, mainly in relation to the existing production potential and the ever-increasing burden of Asian rice imports on the country's meagre foreign currency reserves, the Government of Ethiopia has designated rice as one of the priority commodities with two concrete, five-year, rice-specific interventions related to: (i) enhancing domestic production in rain-fed lowland, upland and irrigated areas, and (ii) strengthening national capacity to boost quality rice processing through improved post-harvest and processing management (Tadesse et al., 2019).

The commercialisation of rice in Fogera Plain after its introduction into Ethiopia in the 1970s is associated with several key factors: (i) the existence of suitable agroecologies and the quest of successive governments to address food insecurity and improve agricultural production in the area; (ii) the compatibility of rice with local farming systems and traditional foods, especially the preparation of 'injera' (traditional flat bread); (iii) the economic incentives of its production related mainly with higher productivity in relation to better unit prices versus other cereal crops; (iv) the emergence of mainly small-scale processors acting as pull factors of rice commercialisation; (v) state concerns about increasing rice imports to meet rising consumer demand, which has put huge pressure on scarce foreign currency reserves; and (vi) the favourable public policy environment and support of international development partners to promote R\&D efforts to increase rice production.

Considering these factors as drivers, in this paper we present first the historical aspects of the introduction of rice and trace its expansion through an analysis of rice production, import and consumption trends under different political regimes since the 1970s. This is followed by an examination of the association between rice expansion as both a driver and an outcome of dynamic agrarian change observed in the Fogera Plain. This paper also presents the differential livelihood impacts covering local people's engagement with the rice value chain, from production to processing and marketing. The paper concludes with reflections on how these processes of agricultural commercialisation and agrarian change are likely to play out in future and what opportunities and challenges remain at both local and national level for fostering structural transformation through investments in the rice sector.

The methodology of this paper builds on a mixedmethods research approach which involved analysing data generated from: (i) three quantitative surveys of smallholder rice farmers, rice processors, and rural labourers conducted in 2018; (ii) in-depth key informant interviews (>25) and focus group discussions (FGDs) (>10) that were aligned with these surveys; 
and (iii) secondary datasets and sources from both governmental and non-governmental organisations (NGOs). Furthermore, we employed a conjunctural, historical perspective approach in this analysis in which we identified key moments (conjunctures) when observable changes happened in rice sector development since the 1970s, examined how these changes influenced the emergence and dynamics of different activities and relationships, and assessed how these effects shaped the livelihood trajectories of different actors in the rice sector, particularly the producers, labourers and processors of Fogera. 


\section{HISTORICAL TRENDS: THE INTRODUCTION AND COMMERCIALISATION OF RICE IN ETHIOPIA}

\subsection{Political economy of agriculture and the introduction of rice}

Rice is a relatively new crop in Ethiopia. Its introduction was linked with the quest for addressing the challenges of different public interventions on food security and resettlement during the Derg Regime (officially the Provisional Military Government of Socialist Ethiopia). The key milestones in the introduction of rice and the rice sector R\&D are summarised in Table 2.1.
The Derg was established in June 1974 as the Coordinating Committee of the Armed Forces, Police and Territorial Army, by low-ranking officers of the Ethiopian Army and Police, led by Chairman Aman Andom. It was formally renamed the Provisional Military Administrative Council and in September 1974 overthrew the government of the Ethiopian Empire and Emperor Haile Selassie during mass protests following the 1973 famine. The Derg abolished the monarchy and embraced communism as an ideology, establishing Ethiopia as a Marxist-Leninist one-party

Table 2.1: Chronology of the introduction of rice and rice sector development in Ethiopia

\begin{tabular}{|c|c|c|c|}
\hline Period & Rice-related event/location & Actors & Achievement \\
\hline 1973 & $\begin{array}{l}\text { Rice testing in Gambella, which } \\
\text { marks the start of rice research } \\
\text { in Ethiopia }\end{array}$ & $\begin{array}{l}\text { Institute of Agricultural } \\
\text { Research/Extension Project } \\
\text { Implementation Department }\end{array}$ & $\begin{array}{l}\text { Upland rice variety "EX Pokwo" } \\
\text { tested }\end{array}$ \\
\hline 1982 & $\begin{array}{l}\text { Trials on irrigated rice for yield } \\
\text { nursery medium duration at } \\
\text { Gambella }\end{array}$ & $\begin{array}{l}\text { International Rice Research } \\
\text { Institute's International Rice } \\
\text { Testing Programme }\end{array}$ & $\begin{array}{l}\text { Lines RP1125-1548-1-4-3 and } \\
\text { RP1125-1526-2-2-3 from India } \\
\text { were tested }\end{array}$ \\
\hline $\begin{array}{l}1984-91 \text { and } \\
1996-98\end{array}$ & $\begin{array}{l}\text { Testing of improved rice } \\
\text { varieties and training for local } \\
\text { experts on variety development } \\
\text { at Gambella }\end{array}$ & $\begin{array}{l}\text { Japanese International } \\
\text { Cooperation Agency volunteers }\end{array}$ & $\begin{array}{l}\text { Promotion of rice as a staple } \\
\text { cereal as well as a cash crop }\end{array}$ \\
\hline 1985 & $\begin{array}{l}\text { Start of public-funded } \\
\text { formal rice research with the } \\
\text { establishment of Pawe and } \\
\text { Abobo Research Centres }\end{array}$ & $\begin{array}{l}\text { Pawe Agricultural Research } \\
\text { Centre (PARC) and Abobo } \\
\text { Agricultural Research Centre } \\
\text { (AbARC) }\end{array}$ & $\begin{array}{l}\text { Promotion of large-scale } \\
\text { rice production linked with } \\
\text { the massive resettlement } \\
\text { programme in both Pawe and } \\
\text { Gambella areas }\end{array}$ \\
\hline 1988 & Large-scale rice production & Tana Beles Project & $\begin{array}{l}\text { Adaptation trials on upland rice } \\
\text { and identified IAC-164, IAC-147 } \\
\text { and IRAT-216 as promising }\end{array}$ \\
\hline 1993 & $\begin{array}{l}\text { Reinitiating rice research for } \\
\text { Pawe area }\end{array}$ & PARC & $\begin{array}{l}\text { Formal release of Pawe } 1 \\
(M-55) \text { variety for Pawe area in } \\
1998\end{array}$ \\
\hline 1991 & $\begin{array}{l}\text { Initiation of rice research at } \\
\text { Fogera Plain }\end{array}$ & $\begin{array}{l}\text { Adet Agricultural Research } \\
\text { Centre (AdARC) }\end{array}$ & $\begin{array}{l}\text { Started rice variety release in } \\
1999 \text { (Gumara, Tigabe, and } \\
\text { Kokit) }\end{array}$ \\
\hline 2001 & $\begin{array}{l}\text { Start of demonstration of rice } \\
\text { varieties (NERICA) }\end{array}$ & $\begin{array}{l}\text { Sasakawa Global 2000/ } \\
\text { Sasakawa Africa Association }\end{array}$ & $\begin{array}{l}\text { Demonstration of improved rice } \\
\text { varieties to smallholder farmers } \\
\text { in different parts of the country }\end{array}$ \\
\hline 2010 & $\begin{array}{l}\text { National Strategy for Rice } \\
\text { Research and Development in } \\
\text { Ethiopia }\end{array}$ & $\begin{array}{l}\text { Ministry of Agriculture and } \\
\text { Rural Development }\end{array}$ & National strategy (2010-2019) \\
\hline 2012 & $\begin{array}{l}\text { Establishment of National } \\
\text { Centre of Excellence for rice } \\
\text { research }\end{array}$ & $\begin{array}{l}\text { National Rice Research and } \\
\text { Training Centre (NRRTC) at } \\
\text { Fogera }\end{array}$ & $\begin{array}{l}\text { Domestic capacity building in } \\
\text { research }\end{array}$ \\
\hline 2020 & $\begin{array}{l}\text { National Rice Development } \\
\text { Strategy-II }\end{array}$ & Ministry of Agriculture & $\begin{array}{l}\text { Revised National strategy } \\
(2020-2030)\end{array}$ \\
\hline
\end{tabular}

Sources: Compiled from various published and unpublished government documents 
state with itself as the vanguard party in a provisional government. The abolition of feudalism, increased literacy, nationalisation, and sweeping land reform, including the resettlement and villagisation from the Ethiopian Highlands, became priorities (de Waal, 1991).

State proponents of the resettlement schemes argued that these would resolve the country's recurring drought problem and would ease population pressure from northern areas where the land had been overused. However, even well-established schemes encountered problems, as many failed to provide adequate livelihood options for their settlers (Grunditz, 2015). Other arguments against resettlement included charges of human rights violations, forced separation of families, and lack of medical attention in resettlement centres, which resulted in thousands of deaths from malaria and sleeping sickness (Clay and Holcomb, 1986; Wubne, 1991).

By the mid-1980s, Ethiopia was ravaged by various pressing issues, including economic decline, persistent droughts and the 1983-1985 famine (the Derg itself estimated more than a million deaths from famine during its time in power) (Gill, 2010). This was followed by increasing reliance on foreign aid and a gradual resurgence of conflicts, particularly the Eritrean War of Independence and the Ethiopian Civil War between the government and various ethnic militias in the periphery. Mengistu Haile Mariam, who became Chairman of the Derg in 1977, formally abolished the regime in 1988 and formed the People's Democratic Republic of Ethiopia (PDRE) led by the Workers' Party of Ethiopia. The new government contained civilians but was still dominated by surviving members of the Derg.

The geopolitical situation in the late 1980s turned unfavourable for the new government, with the Soviet Union retreating from its expansionist agenda under Mikhail Gorbachev's glasnost ('openness') and perestroika ('restructuring') policies. Socialist bloc countries drastically reduced their aid to Ethiopia because they were also struggling to keep their own economies going (Korn, 1986). This resulted in even more economic hardship, and the military gave way in the face of determined onslaughts by guerrilla forces in the north. The Soviet Union withdrew aid to the PDRE in December 1990. This withdrawal, together with the fall of communism in the Eastern Bloc in the Revolutions of 1989, dealt a serious blow to the regime.

Towards the end of January 1991, a coalition of rebel forces called the Ethiopian People's Revolutionary Democratic Front (EPRDF) captured Gondar (the ancient capital city), Dessie and Bahir Dar (the largest city near the Fogera Plain) in Amhara Region. The EPRDF consisted of four political parties, namely Tigray People's Liberation Front, Amhara Democratic Party, Oromo Democratic Party, and Southern Ethiopian People's Democratic Movement and several smaller affiliated groups. After leading the overthrowal of the PDRE, the new coalition dominated Ethiopian politics from 1991 to 2019.

The rise of the EPRDF was made possible in part by the dissatisfaction of rural populations with the unfavourable agricultural policies inflicted upon them. Having capitalised on this rural disaffection to gain power, the new government sought to achieve legitimacy by delivering broad-based growth following a 'developmental state' model (Hauge and Chang, 2019). This translated into sustained efforts to support smallholder producers (more recent efforts to also attract large-scale farming notwithstanding), including significant investment in the national and regional agricultural research and extension systems (Berhanu and Poulton, 2014).

The expansion of rice in Ethiopia after 1991 under the EPRDF was part of a wider programme of investment in agriculture. Accordingly, the introduction of rice in different parts of the country was linked with large public agricultural programmes and initiatives, which were supported by various international development partners (Table 2.1). These early introductions were in three places that subsequently followed different development paths, the Gambella, Pawe and Fogera areas (Bekur, 1997; Sendeku, 2005; Asmelash, 2014). Except Fogera area, both Gambella and Pawe were target areas of public resettlement programmes that settled people from famine-affected areas, mainly from the then Tigray and Wollo areas.

Gambella area: The first intervention was a joint effort of the then Institute of Agricultural Research (IAR) and Extension Project Implementation Department of the Ministry of Agriculture in testing upland rice varieties to explore the potential of the Gambella area in 1973. This was followed by the International Rice Testing Programme of the International Rice Research Institute (IRRI) at Gambella in 1982, and two improved varieties from India were tested. ${ }^{2}$ Recognising the need for research on the new crop, the Abobo Agricultural Research Centre (AbARC) was established in 1985 to lead rice $R \& D$ in the region. It is still operational under the regional Gambella Agricultural Research Institute. The new centre was set up to provide technical support to the resettlement programme of the then 
government, where large numbers of people were resettled, mainly from then the Tigray and Wollo areas (Tadesse et al., 2019).

Pawe area: Parallel to the state-led intervention in Gambella, rice was also introduced in Pawe, which had its own large resettlement programme linked with the establishment of the Pawe Agricultural Research Centre (PARC) in 1985 and the Italian-supported Tana Beles Project in 1988. However, these efforts did not continue and rice production in the area remained insignificant until recently, mainly due to the civil unrest and destruction of the germplasm, which were maintained by PARC. It was in 1993 that rice research was formally reinstated by reconstructing the research centre. This has resulted in formal release of the M-55 rice variety for Pawe area in 1998 (Tadesse, et al., 2019).

Fogera Plain area: The introduction of rice into the Fogera Plain followed another path. One of the agricultural interventions during the Derg regime was the promotion of farmers' cooperatives, where certain international experts from different socialist bloc countries were invited to strengthen the capacity and boost the performance of established cooperatives. Among these experts were North Korean scientists who were placed in Fogera Plain to support two established farmer cooperatives, namely the Jigna Agricultural Producers' Cooperative in Dera woreda (district) and Shaga Agricultural Producers' Cooperative in Fogera woreda. These experts observed the existence of wild rice growing in the area, which served as an indication that the region would be suitable for rice cultivation.

The Korean experts, together with the experts in South Gondar's Department of Agriculture, began research on rice through the introduction of rice varieties from North Korea by engaging members of the farmer cooperatives that had started in the early 1980s. During that period, the area was known as a food deficit region. It had high levels of food insecurity linked with long periods of flooding and low productivity of the staple crops that were grown in the area. According to various farmers and other key informants interviewed for this study, due to the limited knowledge about rice among local communities, the South Gondar Department of Agriculture and North Korean advisors essentially forced local farmer cooperatives to produce rice. It took several years before the cooperative members showed any interest in adopting the new rice varieties willingly. Although the rice grew well, there was little market for it, as local mills were not equipped to dehusk it and local people were not accustomed to eating it. Formal efforts to promote rice production were discontinued when farmer cooperatives ceased in 1991 following the fall of the Derg.
With the relocation of the rice experts from South Gondar Department of Agriculture to Adet Agricultural Research Centre (AdARC) in the early 1990s, formal research on rice started in the Fogera Plain. The initial research effort was designed to evaluate and multiply seed of the rice varieties introduced by the North Korean scientists and provide seeds to farmers at Jigna and Shega kebeles (the smallest administrative unit of Ethiopia, similar to a ward or neighbourhood) where the initial introduction of rice was made. In 1993, about 30 farmer households started growing rice (Gebey et al., 2012; Meron 2016). There is a general agreement that the name ' $X$-jigna' for the popular variety, which is considered 'local' as it comes from the kebele name Jigna, was coined because it was where the North Koreans originally introduced their new rice variety.

Through these initiatives, different varieties were under use without formal variety release and registration. It was at this time that both AbARC in Gambella and $\mathrm{PARC}$ at Pawe were established to start formal rice research as national agricultural research programmes within the then IAR (EARO, 2000). It was in 1998 that the first variety called Pawe 1 (M-55) was released (MoANR, 2016). As rice became one of the most important crops in the Fogera Plain, AdARC started rice research and released an upland rice variety called 'Getachew' (AD-1) in 2007.

Though the research and registration of improved rice varieties received attention, the demonstration and popularisation of the available varieties was limited. It was through Sasakawa Global 2000 (SG 2000), an international NGO, that formal demonstration of improved rice varieties started in the 2001 production season in the country (SG 2000, 2002). Recognising the importance of rice and demonstrated evidence of success in the areas where improved varieties were demonstrated, SG 2000 has expanded the demonstration of improved rice varieties and practices in different parts of the country following the Sasakawa Africa Association (SAA) Board decision in 2004 to establish a new regional rice programme, primarily to expand its work to promote the New Rice for Africa (NERICA) varieties developed by scientists at AfricaRice, formerly the West African Rice Development Association (SAA 2000, 2004). For instance, it was through SG 2000 demonstration of rice varieties that May Tsebri area in Tigray became one of the rice hubs in the country (SG 2000, 2015). Linked with SG 2000 efforts and the Coalition for African Rice Development continental initiative since 2008, the government of Ethiopia designed the National Rice Research and Development Strategy in 2010. This has been instrumental in guiding rice-related policy and development interventions. 
The initial national rice research coordination was handled by PARC and AdARC, which was mandated to support farmers in Fogera Plain, and assumed responsibility for coordinating national-level rice research. Thereafter, the federal government established the new National Rice Research and Training Centre (NRRTC) in 2012 with support from the Government of Japan, and the mandate of national rice research coordination shifted from Adet to Fogera.

Overall, the introduction of rice and attempts at rice sector development have been influenced by the public quest for food security and supporting resettlement programmes, along with support from development partners. With considerable success in the development of improved rice varieties in the country, the historical trends indicate that attempts to promote rice production by linking with resettlement programmes was not successful, even though in some resettlement areas like Chewaka area in Oromia Region settlers are still highly engaged in rice production. In general, the expansion of rice to the different parts of the country was in fact driven by the opportunities offered by the rice sector for better livelihood options, related with the compatibility of rice to existing farming systems and consumption habits, along with the business opportunities rice offered to locals, especially in processing and marketing of paddy and milled rice.

The role of the public sector in rice sector development in the early years (before 2010) was limited and most of the current rice production hubs emerged through smallholder private initiatives. For instance, the expansion of rice production in the Guraferda area in SNNPR Region was made possible by a private initiative of smallholder farmers and processors who tested and expanded rice production and processing in the area (Workye, Goshu and Tegegne, 2019). Similarly, the role of the public sector in promoting available improved varieties, pre-harvest, harvest, and post-harvest technologies along with development of ric- specific skills and expertise in the rice production areas has been very low. However, since the development of a national rice R\&D strategy in 2010 and the recognition of rice as an important crop for import substitution, there has been increased public attention on the crop. One of the public measures was the provision of investment incentives for commercial rice farming along with oil crops and cotton through priority allocation of farmland, which was not successful due to a lack of other provisions including the limitation of repatriation of profits in foreign currency.

\subsection{Trends in rice production, imports and domestic consumption}

The area of domestic rice production has increased considerably due to the expansion of production from wetland areas, mainly in the Fogera Plain, to upland and irrigated areas with the introduction of suitable rice varieties for these agroecologies. In collaboration with AfricaRice and IRRI, the national research system has released improved rice varieties: 20 for rainfed upland, 10 for rainfed lowland and 9 for irrigated ecosystems (MoA, 2018; personal communication). As a result, production levels have been increasing consistently over the years. Data from the Central Statistical Agency (CSA) indicate that rice production increased from 71,320t in 2008 to 171,850 t in 2019 (Figure 2.1). The increasing trends are mainly related with the economic incentives that rice offers to smallholder rice farmers, and the research and extension support provided by the government to ensure food security and import substitution.

Rice imports to Ethiopia have increased significantly in recent years (Figure 3.1). According to data from the Ethiopian Revenue and Customs Authority (ERCA), rice imports skyrocketed from 22,500t in 2008 (with a value of US $\$ 12.07$ million) to 393,330t in 2018 (US\$170 million) (ERCA, 2020). This has burdened the country's meagre foreign currency reserves and alarmed government circles about the rapidly rising demand for imported rice.

There are four main types of rice imported into the country, which are recognised by Ministry of Trade and ERCA. These are: (i) broken rice; (ii) husked brown rice; (iii) rice in the husk (paddy or rough); and (iv) semi-milled or wholly milled rice. These are further categorised into two major types: Japonica type and Basmati type.

The ERCA import data indicates that the major rice exporting countries to Ethiopia are India, Pakistan, China, United Arab Emirates, Thailand, Sri Lanka and Indonesia. India alone accounts for 50 per cent of rice imports into Ethiopia over the past decade (ERCA, 2020).

Considering domestic consumption as the sum of domestic production and imports, the total consumption of rice in Ethiopia has grown considerably. This is in line with the trends in consumption observed in other African countries (Seck et al., 2013; Wopereis et al., 2013). The trend in domestic production and imports 
indicate that the rate of increase was significantly higher for rice imports compared to domestic production, which has resulted in a sharp decline in the rate of selfsufficiency in rice consumption. Consequently, the level of self-sufficiency has declined from about 70 per cent in 2008 to about 24 per cent in 2019. The contribution of the Fogera Plain area to the total national production of rice ranges from 70-80 per cent (Figure 2.1).

This trend poses both advantages and disadvantages. The key advantage is related to the increasing opportunity for Fogera rice farmers to expand their production to meet rapidly growing demand in the domestic market. In addition, rice has been found to be compatible with traditional Ethiopian foods, as people are starting to mix rice and teff when cooking injera. Some people are also using rice to make traditional alcoholic drinks such as tela and arekay. Rice by-products can be used for animal feed and fuel (from the straw, bran and husk) which farmers value. Furthermore, areas once regarded as 'wasteland' (water-logged areas), such as those found in low-land areas of Fogera, can be used as paddy fields. The yield obtained from rice is also relatively higher than that of teff.

A major disadvantage is related to the stiff competition that Ethiopian farmers face from rice exporting countries in Asia, which can supply large quantities of relatively high-quality rice at modest prices, and often below domestic market prices. Another challenge is that rice production has been increasing rapidly due to area expansion, meaning that productivity per unit area remains low compared to Asia. In addition, there is a shortage of pre-and post-harvest processing technologies and most farmers are unaware of post-

Figure 2.1 Trends in domestic production, import and consumption, 2008-19

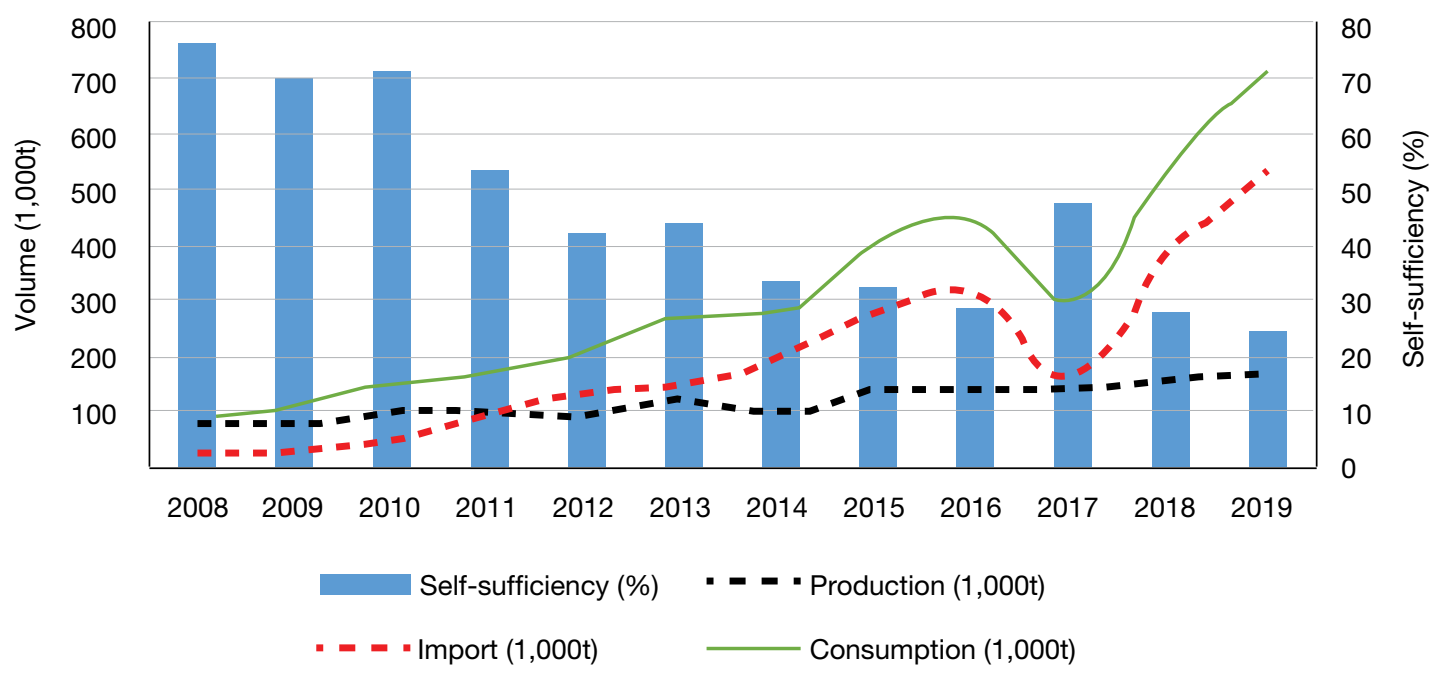

Source: Based on data from CSA and the Ethiopian Ministry of Revenue (2008-2019) harvest management and utilisation methods. As a result, the quality of rice remains low and has not made its way into Ethiopian supermarkets. Instead, most of the locally-produced rice is processed into flour. 


\section{RIGE COMMERCIALISATION AND AGRARIAN GHANGE}

With increased commercialisation of rice, there has been diverse and dynamic changes in agrarian relations in the Fogera Plain. In general, agrarian change is associated with changes in farming systems, land tenure, labour and other input markets, ruralurban linkages and changing social relations (Lewis, 2002; Borras, 2003a and 2003b; Tsikata, 2015; Wise and Veltmeyer. 2016). In this regard, we identify five main processes of agrarian change affected by, and affecting, rice commercialisation in the Fogera Plain. These are: i) changes in the farming systems; ii) dynamism in the land tenure systems; iii) changes in rural labour and gender relations, iv) changes in the type and use of agricultural technologies; and (v) changes in rural markets and rural-urban linkages. The changes linked with rice commercialisation in the Fogera Plain are presented below.

\subsection{Farming system dynamics}

The introduction and expansion of rice in the Fogera Plain has brought considerable land use change with differentiated results in the two major agroecologica zones found in the area. Through a series of FGDs and historical trend analyses with rice farmers, extension agents, subject matter specialists and rice researchers, we assessed changes in the upland and lowland zones and documented six major categories of agricultural production, including rice, other cereals, vegetables, pulses, oil crops, and livestock. The relative importance of each crop in Figure 3.1 was determined using land allocation and contribution to household income.

\section{Land use patterns in upland rice agroecological}

zone: As depicted in Figure 3.1, rice production was unknown in the upland areas of the Fogera Plain some three decades ago. Linked with the introduction of upland rice varieties through the national research system, the production of rice has emerged as one of the primary production options, and rice is now the fifth most important crop in the country. This zone also produces cereals (teff, maize and millet), and pulses (chickpea, lentils, and grass pea). Trends show that the production of cereals, rice and vegetables has been increasing while there has been a decline in the importance of oil crops and livestock.

Figure 3.1: Change in land (1990s to 2018)
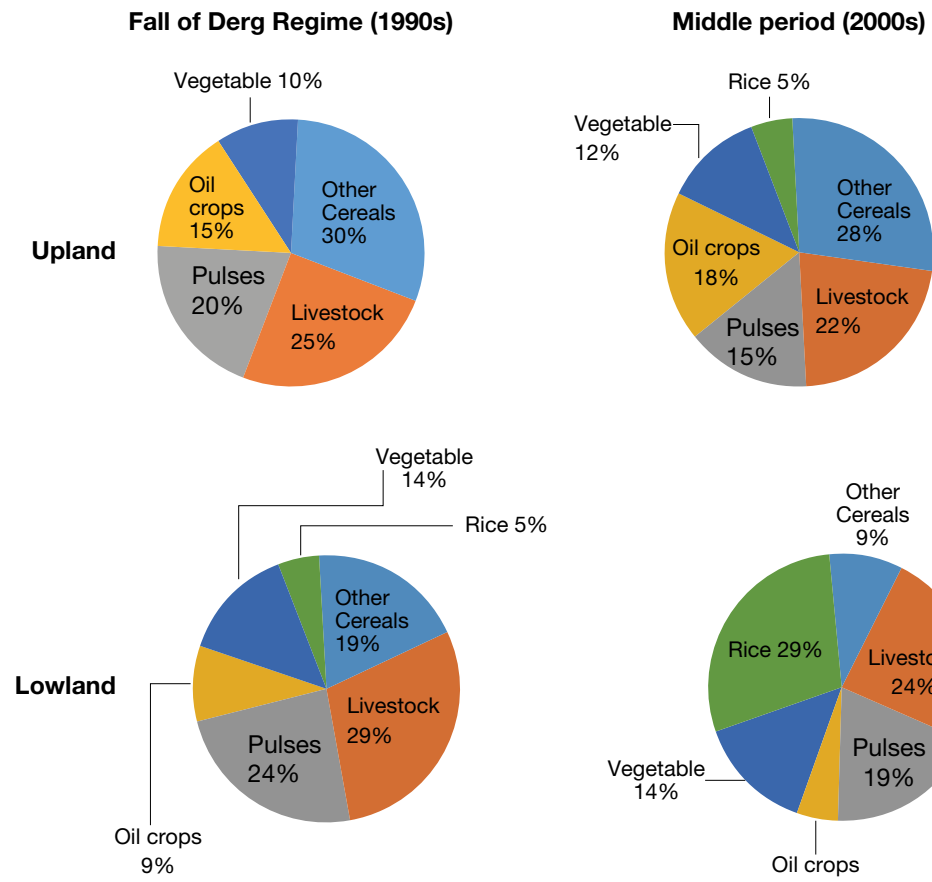

Recent period (2018)

Source: Authors' own
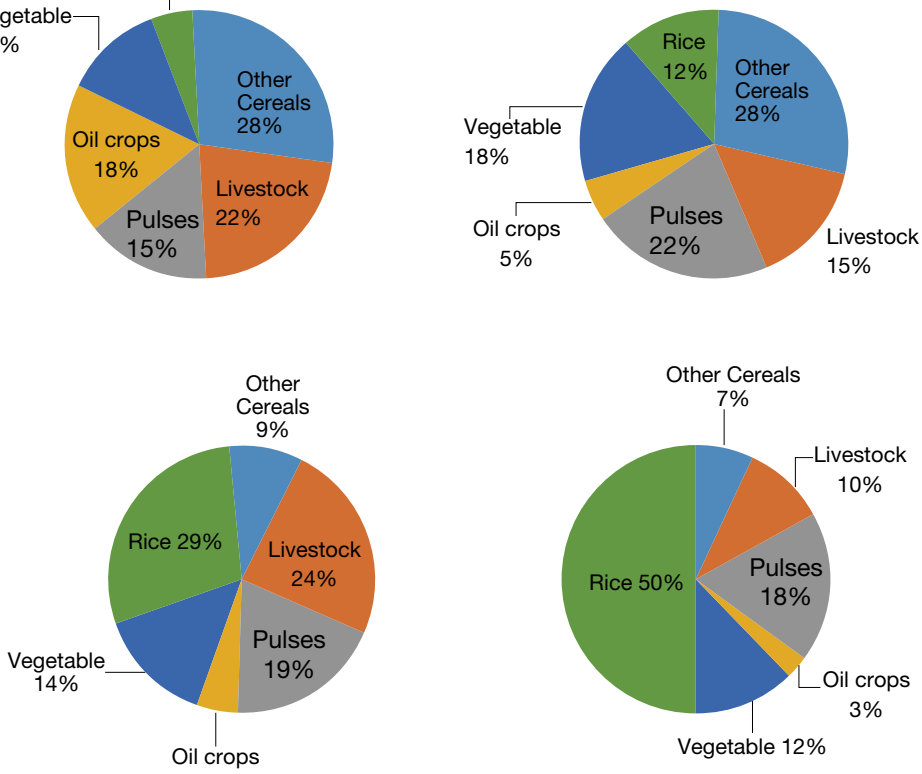


\section{Land use patterns in lowland rice agroecological}

zone: The lowland agroecological zone has been the most food insecure area in Fogera due to persistent flooding and waterlogging during the main production season. Accordingly, livestock and pulses that grow on residual moisture play an important role in the livelihoods of smallholders. Traditionally, this lowland area was known for its Fogera breed cattle, which has a large frame, is well suited to the bogging soils and is one of the best native milk cows in Ethiopia. However, because other breeds of cattle are brought from Dera and Kemekem woredas to the plains in the dry season, the local breed is at risk of genetic dilution.

Furthermore, increasing competition from rice production means that there has been a considerable shift in the land use pattern, and grazing land has been diminishing. Today, rice plays the dominant role in the farming system, followed by pulses and vegetables. Overall, most of the pulses, such as grass pea and chickpea, help to improve soil fertility, and act as a second crop after rice. Vegetables are also produced using irrigation and are used as a second crop. These have become important both for home consumption and as additional commercial crops.

The trend in smallholder rice farmers' investment in water pumps indicates a considerable increase. Data from Fogera District Office of Agriculture indicate an increase in ownership of water pumps from 2,010 in 2017 to 4,588 pumps in 2020 to produce vegetables (Table 3.1).

Overall, trends indicate that there has been a considerable shift in land use towards more commercially viable commodities such as rice, pulses and vegetables, with a decline in other cereals and livestock in the district. This shift has influenced and been influenced by significant changes in the local land tenure system, with the emergence of dynamic formal and informal land markets which have created new opportunities for some, while posing barriers for others.

\subsection{Land tenure dynamics}

Increased agricultural commercialisation has been among the key factors leading to the emergence of different forms of land transfers. In this regard, there has been considerable debate on the role of agricultural commercialisation in land transfer and its implication for smallholder farmers' livelihoods and overall transformation of smallholder agriculture (Yaro, Teye and Torvikey, 2017). In Ethiopia, the issue of land has been at the centre of all political changes. During the imperial era before 1975, land was concentrated in the hands of absentee landlords and much of the land was severely underutilised. During the Derg regime, ownership of all rural land was transferred to the state for distribution of use, and rights to cultivators were provided by local peasant associations. Following the fall of Derg in 1991, rural land was administratively allocated to farmers who were granted long-term use-rights. However, based on the new Rural Land Administration Proclamation, No. 89/1997, regional governments were assigned the responsibility of land administration, defined as the assignment of holding rights and the execution of distribution of holdings. Holding rights of smallholders were confined to: (i) use only for agricultural purposes, (ii) lease for agricultural purposes, and (iii) to bequeath to a family member (Deininger et al., 2003).

Linked with the challenges of the land administration since 1997, especially in terms of limited tenure security, the government designed a programme of land ownership certification, which is reported to have reduced land border conflict, helped to empower women, and improved governance at the local level, and is expected to have an impact in terms of investment and productivity impacts (Deininger, Zevenbergen and Ayalew, 2006). As per the provision of Federal Rural Land Administration Proclamation, No. 89/1997, a regional proclamation on rural land administration was enacted in 2017 (Proclamation no 252/2017) in Amhara region. To ensure the implementation of the

Table 3.1: Trends in water pump ownership in Fogera district (2017-2020)

\begin{tabular}{|l|l|l|l|l|l|}
\hline \multirow{2}{*}{ Type } & \multirow{4}{*}{ Indicator } & \multicolumn{4}{|c|}{ Year } \\
\cline { 3 - 6 } & & 2017 & 2018 & 2019 & 2020 \\
\hline \multirow{4}{*}{ Ground water } & Existing & 15 & 90 & 385 & 858 \\
\cline { 2 - 6 } & Newly purchased & 75 & 295 & 473 & 670 \\
\cline { 2 - 6 } & Subtotal & 90 & 385 & 858 & 1,528 \\
\hline \multirow{3}{*}{ Surface water } & Existing & 1,778 & 1,920 & 2,046 & 2,466 \\
\cline { 2 - 6 } & Newly purchased & 142 & 126 & 420 & 594 \\
\cline { 2 - 6 } & Subtotal & 1,920 & 2,046 & 2,466 & 3,060 \\
\hline Total & & 2,010 & 2,431 & 3,324 & 4,588 \\
\hline
\end{tabular}

Source: Fogera District Office of Agriculture (2020) 
proclamation, Rural and Administration Directive No 1/2018, Land Use Directive No 2/2018, and Kebele Development Centre Directive No 4/2018 were enacted and implemented.

There is a dynamic interplay between the expansion of rice cultivation and marketing, and changing land tenure arrangements in Fogera. Within the prevailing agricultural policy framework in the region, land markets follow two approaches, land sharing and land leasing, which involve both formal (government-sanctioned) or informal (farmer-managed) arrangements. In addition, due to the increase in the number of landless youths in the wider region, the government has introduced a special land allocation scheme of former common grazing lands to establish them as new farmers. In this section, we examine: (i) the role of rice production and commercialisation in influencing local land markets, (ii) the prevailing land transfer mechanisms, and (iii) the key challenges and opportunities emerging from the different land transfer mechanisms.

a) Rice production and commercialisation and local land markets: The quest for improved household livelihoods and the opportunities arising from rice cultivation and marketing have incentivised farmers to expand the level of production by accessing more land through sharing or leasing. FGDs and interviews with local land administrators revealed that most farmers share or lease land to expand rice production, or for other high value crops (mainly vegetables). In general, both market-led and administrative (state-led) land transfers prevail in the area. There are different views about the appropriateness of the two approaches. Proponents of market-led land transfers argue that the state-led approach distorts the land market by preventing more efficient producers from acquiring or accumulating lands and sustaining the exit of inefficient farmers. Critics of market-led transfers assert that they promote inequity and social exclusion (Borras, 2003a).

b) Land transfer mechanisms: Historically, there have been large land redistribution programmes under both the Derg and EPRDF regimes. The last land redistribution in Fogera Plain was made in 1997 (1989 EC). The redistribution was conducted using land taken from households who owned more than 3ha. For former Derg officials (rural public officials), land over tha was taken and redistributed. The redistribution considered mainly family size and landless youth with dependents and the decisions were made by a local committee composed of farmers and local administrators. This approach also has political dimensions as it targeted the transfer of land from well-to-do farmers and formerly politically-active farmers, to farmers with new political power. Due to increasing conflicts among farmers over land and the limited confidence in earlier administrative arrangements, the government implemented a national programme to issue a land ownership certificate in 2005 (1997 EC), which was called 'the first-round certification'. This was one of the largest, fastest and least expensive land registration and certification programmes in Africa (Deininger et al., 2008).

While there is some variation in how land registration and certification has been implemented across, and even within, regions in Ethiopia, including Amhara, the broad-scale first-stage land registration and certification involved the registration and demarcation of land plots using simple local technologies that required little training. The main sources for determining plot boundaries were field markings, in conjunction with the memories of the neighbours whose farm plots bordered those owned by the households in question. Measuring tapes and ropes were used to measure the farm plots. While the initial cost of this registration was extremely low (approximately US\$1 per farm plot or less), its impact in improving tenure security was reported as being significant, as evidenced by increased investment, land productivity and land rental market activity (Deininger et al., 2008; Deininger, Ali and Alemu, 2011).

However, the first round did not use GPS coordinates to demarcate property boundaries, which created some problems. In 2013, the government began piloting and introducing a second-stage land registration and certification system in selected districts in the highland regions, including in Amhara. The new registration and certification system involves registering the precise geographical locations and sizes of individual farm plots using technologies such as GPS, satellite imagery or orthography (Bezu and Holden, 2014; Persha, Greif and Huntington, 2017). Farmers receive plot-level certificates with maps rather than a household-level certificate. The aim is that the second-stage land registration and certification effort will enhance tenure security, the maintenance and updating of records, and land management (MoA, 2013). This appears to have reduced conflicts among farmers over boundary issues and allowed some of them to use the certificate as collateral to access formal loans. Though a farm household can have more than one land ownership certificate, it is only allowed to have one certificate per kebele. In practice, however, there are households with several ownership certificates because of land ownership in other kebeles or inheritance of land within a kebele.

Within these prevailing policy frameworks, the land markets in Fogera Plain follow two approaches, namely land sharing and leasing, which are either formal or informal legal arrangements. In addition, due to an increase in the number of landless youths, 
former common grazing lands have been allocated to farmers. Both mechanisms are governed by the revised directive of the Amhara Region (Land Administrative Directive No 1/2018) which stipulates how the lease or share arrangements are performed:

- $\quad$ All land sharing and lease arrangements between farmers must be registered either at kebele or woreda level for the purpose of promoting standardised agreement formats for ease of dispute settlement;

- Both traditional and formal arrangements are recognised for land sharing or leasing. The traditional arrangements are those that are for a short period of time, often one year sharing or lease, and agreements are signed in the presence of a local elder. The formal arrangements are those that are registered either at the kebele or woreda land administration offices. The local land administration committee, together with the kebele land administration expert, prepares the agreements to be signed by farmers who are expected to lease/share in/out land. Land sharing or leasing arrangements for a designated period (ranging from 3 to 30 years) requires official approval and registration at district level. Lease or share agreements for a period of less than three years are managed at kebele level.

- The directive stipulates that the purpose of land use is restricted to be only for agriculture.

The FGDs conducted by the authors in the Fogera Plain indicated that there are several challenges in the market-led land transfer systems. The first challenge is related to the enforcement of legal agreements, especially for poor and female-headed households, as the legal process is reported to be very bureaucratic and costly. The second is related to the limited efficiency of the land transfer market system. It is difficult for a household to be aware of available land that can be rented and shared as there is no adequate information system in the area.
The other land transfer mechanism is the administrative land allocation to rural youth, mainly distribution of communal lands. With increased landlessness in different parts of the country, there is a trend of allocating communal grazing land to youth who are married. This appears to have dramatically accelerated land allocations; close to 1,600ha of land was distributed to 2,950 young families in Fogera woreda between 2008-18. Though this has created opportunities for landless young families, the continued decline of grazing areas has a direct impact on livestock production, especially for wellknown Fogera cattle breed that are well adapted to waterlogged areas.

\subsection{Dynamism in rural labour markets}

The expansion and intensification of rice production in Fogera has been associated with the emergence of a thriving off-farm labour market. Demand for unskilled rural labour for land preparation, cultivation, weeding, harvesting, and product sorting and loading and similar activities have grown considerably. Older farmers reported that younger family members without land have found good opportunities in the rural labour market as both daily and contract labourers. Labour demand at peak periods of the agricultural calendar (e.g., weeding, harvesting) is so high that migrant labourers are also being attracted to the region. The rice farmers' survey indicates that 55.4 per cent of them use hired labour for operations such as ploughing, weeding, harvesting and/or threshing. The average man-hours of hired labour is estimated to be 55.3 hours, which is about a weeklong period per smallholder rice farmer. As expected, more farmers use hired labour for weeding and harvesting, which is around 40.5 per cent of the farmers, respectively (Table 3.2).

The participation of female workers in the labour market is an emerging phenomenon, where about 6 per cent of hired labour was provided by women. The rural wage ranges from about 50 Birr/day ( US\$1.5) during harvesting to 100 Birr/day during weeding. The

Table 3.2: Proportion of smallholder rice farmers using hired labour by operation

\begin{tabular}{|l|l|l|l|l|}
\hline \multirow{2}{*}{ Operation } & \multirow{2}{*}{$\begin{array}{l}\text { Percentage of } \\
\text { farmers }\end{array}$} & \multicolumn{3}{|c|}{ Average man-hours hired } \\
\cline { 2 - 5 } & Mean & Std & N \\
\hline Ploughing & 11.10 & 16.92 & 85.28 & 73 \\
\hline Weeding & 40.20 & 30.18 & 102.97 & 258 \\
\hline Harvesting & 41.10 & 27.74 & 27.91 & 270 \\
\hline Threshing & 21.10 & 23.80 & 17.35 & 138 \\
\hline Total hired labour & 55.30 & 55.29 & 119.07 & 358 \\
\hline
\end{tabular}

Source: APRA survey of rice farmers (2018) 
wage variability is due to the shortage of labour during peak weeding time as it overlaps with the weeding time of sesame, an important source of income for casual rural workers in the lowland areas in the north-western part of the country.

\subsection{Changes in the type and use of agricultural technologies}

Farmers reported an increased use of modern agricultural technologies such as quality seed of preferred varieties, agro-chemicals (chemical fertiliser, herbicides and pesticides), and irrigation technologies (water wells and pumps). As a result, they have increasing yields per unit of land and labour. However, there have been reports that this intensification of production is having a negative impact on soil fertility, leading many farmers to adopt the intercropping of nitrogen-fixing grass pea and other legumes, and encourage some to apply increasing amounts of urea and other artificial fertilisers to sustain their yields.

\subsection{Changes in rural markets and}

\section{rural-urban linkages}

Rural input and output markets in the Fogera Plain have been expanding as rice production and commercialisation has increased and demand for rice and rice products have grown, both locally and regionally. A dynamic land market has emerged (mainly related with land rent), as well as rural agricultural product markets, private rural services (input suppliers, transport providers, processors, etc.), and brokerage locally called 'Delala'. Though rural land sale is prohibited by law, land rental has become a common practice in the area. Farmers reported that during the 2017 production year, the average land rent was roughly 12,000 Birr/ha (US\$500/ha).

Given the expansion of rural roads, most farmers now have the option to sell their agricultural produce in nearby urban centres giving them the opportunity to secure better prices when compared to spot sales to local brokers and village markets with a relatively small number of buyers and limited market information. These increased rural-urban linkages have also led to the growth of new transport services to move people and agricultural produce to and from nearby towns, as well as the growth of restaurants, coffee houses and goods shops.

These changes, driven by the expansion of rice production and commercialisation, have led the Fogera Plain to be seen by both government officials and local people as a land of surplus with diverse livelihood options, rather than a land of persistent poverty and food insecurity. This is the main reason why farmers in the region call rice "our white gold". 
The expansion of rice production and its commercialisation has brought diverse livelihood improvements directly to farming household in Fogera. Other actors in the rice value chain have also benefitted directly from the spill-over effects in terms of non-farm investments linked to increased farm household income. Indirectly, growing incomes from rice have led to increased demand for goods and services that have attracted investment in different sectors, including hospitality, banking, transportation, wholesale, and retailing.

\section{1 llmproved livelihoods of smallholder rice farmers}

With the expansion of rice production and its commercialisation, there has been a gradual differentiation of farm households in terms of their income levels, farming practices and associated investments in their own agricultural lands and the diversification of their off-farm business engagements. On-farm investments have included expansion of irrigation facilities involving the development of water wells and purchase of diesel water pumps, particularly to produce high-value horticulture (mainly onion and tomato) and seed crops. Off-farm activities include trading, agro-processing, transport services (where many enterprising farmers have purchased threewheel vehicles locally known as 'bajaj', agricultural product transport vehicles locally called 'Isuzu', and public transport vehicles, mainly minibuses), and construction of houses as rental properties in nearby urban centres.

The differentiation in business engagements is related with the shift of local farmers into farmer traders, who are engaged in paddy rice trade in addition to rice production or local processors, who invest in rice processing. Considering these changes, it is possible to categorise rice farmers in the Fogera Plain into three major types: (i) those who produce and sell rice as their major household activity to sustain their livelihood, (ii) those who produce rice as a commercial activity by investing in agricultural technologies such as improved agro-inputs and investment in irrigation facilities, and (iii) those who invest in rice production and use their agricultural income to invest in off-farm businesses (trading, processing, transport, rental properties, etc.). As indicated in Section 3.2, changes in federal agricultural policies, especially the land redistribution policy of 1998, also contributed to the overall change in the type of rice farmers in the Fogera Plain, by providing youth farmers with land, enabling previously landless farmers to operate using leased land, and for other farmers to scale up their operations.

According to Ethiopian policy, households facing continuous food shortages for three months or more are considered as chronically food insecure (Gilligan, Hoddinott and Taffesse, 2008). ${ }^{3}$ Historically, the three districts of the Fogera Plain (Dera, Fogera and Libokemkem) used to be among the districts labelled as 'food insecure' by district officials, and they therefore annually received food aid managed by the District Office of Food Security and Emergency. However, following the introduction of rice and its gradual expansion and commercialisation, Fogera and Dera districts and rice-producing kebeles of Libokemkem have been recategorised as 'food secured' districts. Reflecting this change, since 2003 the respective offices of Food Security and Emergency have been changed to the offices of Early Warning and Response. Libokemkem district is still considered as food insecure as it belongs to the Productive Safety Net Programme (PSNP) which provides regular support to chronically food insecure households, mainly in kebeles that are not engaged in rice production. With the ongoing effort of promoting upland rice, the food security situation in the Libokemkem district of the Fogera Plain is expected to change significantly in the coming years.

3 In 2019, there were 13,770 chronically food insecure households from the 40,000 estimated total number of households in Libokemkem district under the Productive Safety Net Programme (PSNP) getting support either in the form of food for work or food aid. 


\subsection{Emergence of the rice processing industry}

With increasing rice commercialisation, along with an increased number of smallholder farmers engaged in rice production, there was an associated rapid emergence of rice processing industries in nearby towns in Fogera Plain, which has created dynamic rural-urban linkages as key characteristics of agrarian changes. From a single rice processor in 1997 for the whole of the Fogera Plain, there were 123 registered rice processors in 2018 (Figure 4.1). The average annual growth in the number rice processors is estimated at 34 per cent over the last two decades (1997-2018).

Theoretically, this value addition work includes both primary and secondary processing, where primary processing involves the conversion of raw materials (paddy rice) to food commodities (milled rice) and secondary processing involves the conversion of ingredients into edible products, which combines foods in a particular way to change their properties, like baking cakes. Rice processors in the Fogera Plain are all engaged only in primary processing. However, with the emergence of injera-making from a mix of teff and rice flour, secondary processing of rice at household level has become more common in the area in the past five years.

The emergence of the rice processing industry is not only a business opportunity for the processing facility owners. It has also stimulated the expansion of rice production and marketing in the area, creating rural and urban job opportunities, and investment in nonfarm areas.
The rice processing industry also engages with other service providers, including paddy rice collectors (who act on behalf of the processors), brokers and transporters. For instance, the numbers of assemblers (independent buyers of rice smallholder farmers who sell on to processors) is estimated to range from 20 to 75 , depending on the kebele. This highlights the role of rural-urban linkages between rice farmers and processors through assemblers, who often also live in towns such as Wereta town, which is the largest urban settlement in the Fogera Plain with a population approaching 30,000 people.

Although the emergence of this dynamic rice processing industry has enhanced the livelihood options in the Fogera Plain, the industry still faces important challenges, including accessing a reliable supply of paddy, sub-standard processing technologies, limited availability of other required facilities, complex rice market factors, and inadequate policy support.

a. Paddy supply: the challenges identified related to paddy supply are the poor quality of the rice, shortage of supply, and the need to ensure timely aggregations. Rice is generally produced by smallscale farmers using diverse types of rice varieties and agronomic practices resulting in different quality of paddy, mainly in terms of grain size and moisture contents. In general, uniformity of grain size with appropriate moisture content are key requirements for improved milling recovery and good quality of milled rice (Poonam, 2014). In this regard, about 93 per cent of the rice processors reported the poor quality of paddy supplied by farmers as a major impediment to improving their

\section{Figure 4.1 Trends in the number of rice processors in Fogera Plain}

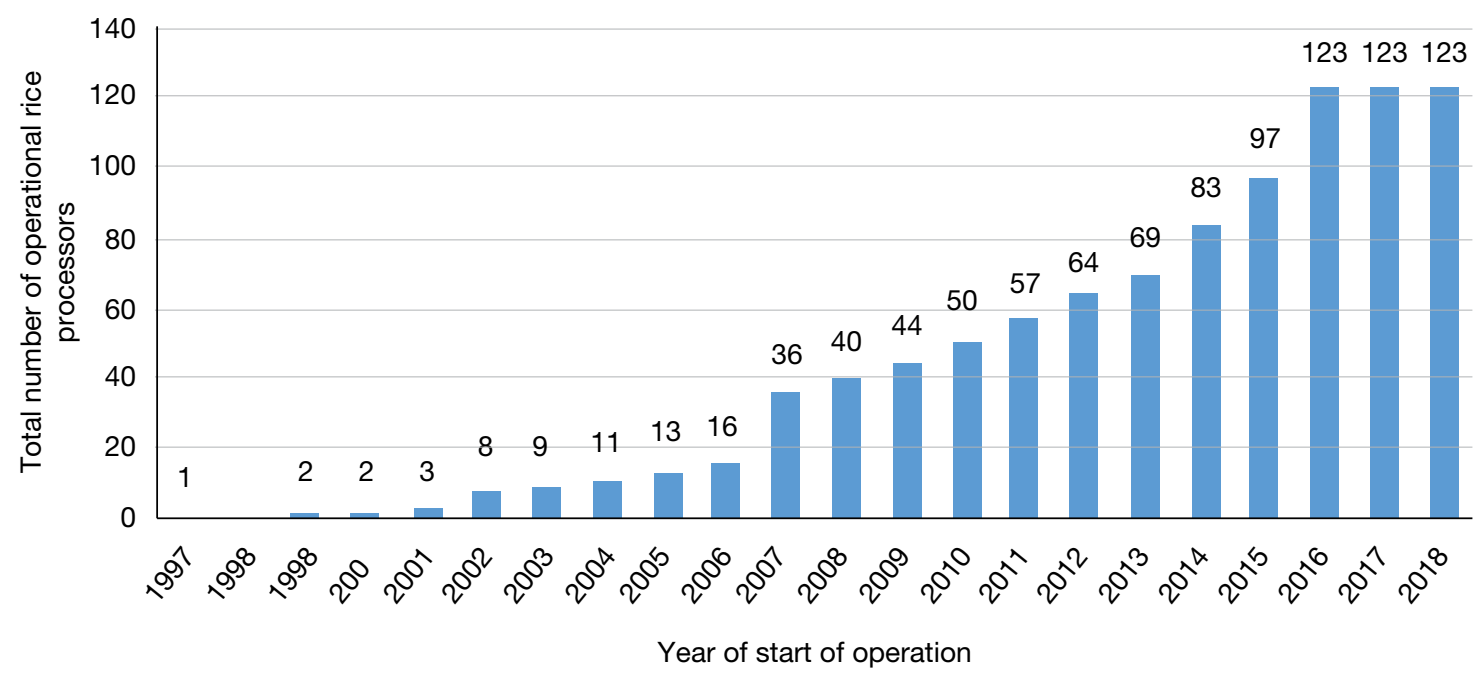

Source: APRA survey of rice processors (2018) 
product. Periodic shortage of paddy supply in relation to the available processing capacity was reported by about 85 per cent of processors, although just over 50 per cent reported aggregation as their primary challenge.

b. Processing technology: About 52 per cent of the processors stated that the processing machines are older models with limited efficiency and 63 per cent reported that modern machines are not available in the local and domestic market. Some were seeking to obtain new processing equipment from as far away as the Middle East and China. However, this required significant foreign capital, which restricted their ability to purchase the machinery. Securing spare parts was also a concern.

c. Required resources and services: Processors reported limitations related with access to land, finance, skilled labour and electric power as key challenges to sustain and expand their rice processing businesses. Of these constraints, limited access and interrupted supply of electric power (91 per cent), and limited access to required finance (73 per cent), were reported as the most important ones. These were followed by limited access to land for expanding their operations (59 per cent) and for establishing other businesses (54 per cent). Furthermore, just over half (52 per cent) of the processors noted that the lack of skilled labour for operating their processing machinery was a limitation.

d. Rice markets: In terms of rice marketing, competition from imported rice was reported by 72 per cent of the processors. Many found it hard to compete either on quantity or quality terms. They explained that there was an inadequate local demand for milled rice (62 per cent). Furthermore, there was a limited price incentive for quality paddy and milled rice (59 per cent), as much of the locally-produced rice was used in flour for injera. Finally, over two-fifths of processors (44 per cent) complained about the lack of market information about price, place and time of sale to allow them to expand their commercial activities.

e. Policy environment: There is no public service in Ethiopia designed to ensure access to improved, low-cost technology for the processing of rice. Technology management skills are also lacking. These constraints help explain the prevalence of inefficient processing practices. Furthermore, there is no national standards or guidelines for setting up rice processing facilities, specifically in relation to the types of machinery required, byproduct management, packaging and storage facilities, and so on. Local authorities in Fogera engaged in allocating land and business licenses to rice processors do not appear to be aware of what is required to facilitate the establishment of proper rice processing facilities.

\subsection{Expansion of other private businesses and urbanisation}

Despite some of the challenges noted above, rice is transforming the Fogera area. With increased incomes for both rice farmers and processors, several business opportunities have evolved in and around the urban centres in the region. The most important relate to the expansion of hotels, wholesaling, retailing and banking, all of which have developed as towns have expanded. The boom in businesses has also led to growing demand for more and better public services, which in turn has led to the establishment of a number of government offices and other public organisations, including a dry port service centre, and an inland port which provides customs services, to reduce port service fees for goods imported from the Republic of Sudan. These are all contributing to the expansion of new livelihood options in the Fogera Plain (Tadesse, Alemu and Assaye, 2020).

Specifically, the expansion of these businesses and services has contributed indirectly to the emergence

Table 4.1 Expansion of businesses in Wereta

\begin{tabular}{|l|l|l|l|}
\hline Category & Types of businesses & Number in 2010 & Number in 2020 \\
\hline $\begin{array}{l}\text { A - those with investment greater than 1 } \\
\text { million Birr (US\$30,300) }\end{array}$ & All types of businesses & 0 & 78 \\
\hline $\begin{array}{l}\text { B - those with investment ranging from 0.5- } \\
1 \text { million Birr (US\$15,150-US\$30,300) }\end{array}$ & All types of businesses & 62 & 148 \\
\hline $\begin{array}{l}\text { C - those with investment less than 0.5 } \\
\text { million Birr (US\$15,150) }\end{array}$ & $\begin{array}{l}\text { Mainly shops, kiosks, coffee } \\
\text { houses, and local liquor, tela } \\
\text { and teji (alcohol) houses }\end{array}$ & 809 & 1,516 \\
\hline
\end{tabular}

Source: Adapted from Wereta Trade and Investment Office (2020) 
of hospitality services, private investments, financial service providers, and public organisations. Considering Wereta city, the capital of Fogera district, the hotel industry has become a central feature of the local economy and, with increased economic activity driven by rice, the number of hotels and restaurants has increased markedly over the past decade. This not only provides critical hospitality services for temporary residents and visitors, but also creates important, off-farm job opportunities. With the expansion of the city and increase in economic activities, the trade and investment in private businesses is flourishing (Table 4.1). These trends clearly indicate how private investment has flourished across the city, which has stimulated the income for locals through the creation of further jobs.

The dynamism of the local economy in Wereta has sparked increased demand for financial services. Eight banks have opened branch offices in the city, namely the public Commercial Bank of Ethiopia (two branches), as well as six private banks, including Abay, Abyssinia, Awash, Buna, Dashen, Nib and United. This growing concentration of banks indicates the considerable demand from locals for banking services and the extent of financial transactions. It is common to see long queues of farmers waiting for banking services on market days.

With the increase in urbanisation and the demand for linking with rural kebeles, the call for public transport services has also increased. This has allowed individuals with better incomes to make use of bajaj (three-wheel motorcycles), minibuses, and buses. Some farmers have used the income from their rice sales to invest in these vehicles, thus diversifying their livelihood strategies, while providing a vital local service.

Similarly, demand for the transport of goods - mostly agricultural and construction materials - has also increased substantially, mainly using medium-size trucks (Isuzus). Consequently, the number of fuel stations has increased and there are currently eight stations in Wereta city alone, where only a decade ago only one existed.

With the growth of these urban centres has come increased demand for public services. Several public organisations have been established, as well as new public district administration offices, including those related to the development of the rice sector in the region:

- $\quad$ The NRRTC of the Ethiopian Institute of Agricultural Research (EIAR), which has a mandate for national coordination of rice-related research and for conducting rice research in different areas. NRRTC is engaged in promoting diverse ricerelated technologies and the facilitation of rice stakeholder linkages.

- Wereta Agricultural Technical Vocational Education and Training College (ATVET). The country has 25 operational ATVETs (five federal and 20 regional); the Wereta ATVET is one of the 20 regional colleges responsible for providing training for agricultural development agents and small enterprises in rural areas. Wereta ATVET was established in 1991 and currently runs five departments with 205 permanent staff.

- Wereta Technical Vocational Education and Training College (TVET) was established in 2013 and now runs eight departments (areas of specialisation) with 86 staff. The main objective of Wereta TVET is to prepare a competent workforce for improved employability in the labour market, and enhanced self-employment. TVET trainees are those that did not pass the national exam at grade 10 in the town and surrounding areas. They are provided with training on road construction, plumbing and sanitary installations, surveying, construction management, electrical system installation, carpentry and joinery, textile design and manufacturing.

- The Office of Small and Medium-Scale Entrepreneurship Creation promotes job creation mainly for youth and women by facilitating business start-ups and has been instrumental in supporting new rice processors to set up their businesses. In 2019, two youth groups were established to engage in the rice-husk briquette industry (energy conversion of the husk) in collaboration with Mennonite Economic Development Associates, an international NGO engaged in rice sector development.

\subsection{Opportunities for youth and women}

With increased commercialisation of rice in the Fogera Plain, and emerging trends in agrarian changes, there has been also emerging interlinked opportunities related with youth and women. As key actors in the rice value chain as farmers, processors and labourers, both women and youth seem to benefit from rice commercialisation. A survey conducted in the Fogera Plain in 2018 indicated that about 11 per cent of smallholder rice farming households are femaleheaded and of those 82 per cent are either divorced or widowed and the remaining 18 per cent are single. In terms of resource ownership, female-headed rice 
farming households are, on average, less endowed with household labour given the smaller family size, estimated at about four persons compared to about six persons for male-headed rice farming households. Similarly, the land allocated for rice production is, on average, smaller compared to male-headed households. On average, female-headed households are allocated about 0.5ha of land and male-headed households are allocated about 0.75ha. Similarly, fewer female-headed households (35 per cent) have access to irrigation compared to male-headed households (47 per cent). The challenges facing female-headed rice farmers, mainly in relation to limited land resource and labour availability, seem to be addressed by emerging trends in the land and labour markets. The emerging rural labour market has, for example, created the opportunity for female-headed households to use hired labour for timely accomplishment of farm activities.

In terms of the opportunity created in rice processing, the 2018 rice processors' survey indicated that among 123 rice processors found in Fogera, 11 processors (10 per cent) are female owned. The 2018 survey indicates that all female rice processors hire permanent labour, estimated at about four employees per processor on average. About 84 per cent of the male processors indicated that they hire on average five employees. Some 73 per cent of the female processors indicated that they hire on average five casual day labourers and 68 per cent of male processors hire on average nine casual day labourers. Both male and female processors hire more male labour compared to female labour.

The emerging labour market has created job opportunities mainly for landless youth and women without formal jobs. The 2018 rural labourers' survey in the Fogera Plain indicates that from the total sampled labourers (265), 66 per cent were landless and fully dependent on the labour market, 15 per cent were women, and almost all labourers came from Fogera Plain. The employment opportunities created are not only related with the casual and permanent employment opportunities to support different rice farm operations on smallholder rice farms, but also involve different activities at rice processing facilities, and job opportunities created by emerging businesses from the spill-over effects of rice commercialisation, including hospitality and tourism, banking, fuel stations, other processing industries, and smaller businesses. The emergence and expansion of small businesses often managed by women, like restaurants, coffee houses, and kiosks, has contributed tremendously to empowering women to earn their own livelihoods and creating job opportunities for others.

Considering empowerment of youth and women as a process, in which they are able to accomplish their objectives, rice and its commercialisation, along with the different public measures put in place, has created the opportunity for youth and women to: (i) access to resources (land), (ii) engage in rice farming and processing activities, and (iii) get employment opportunities as casual or permanent employees for rice farming and processing activities. Indirectly, youth and women have also been able to: (i) engage in hospitality and other service provision businesses, and (ii) get employment opportunities as casual or permanent employees for the emerging service and hospitality industries. 
The commercialisation of rice in Ethiopia following its introduction in the 1970s - with the initial objective of addressing food insecurity, along with support to people in government resettlement programmes from drought-affected areas - has largely been a success story in the Fogera Plain. This is reflected in the mainly positive trends observed in changes in farming systems that have supported increased intensification and expansion of rice cultivation, the emergence of an improved land tenure system that created new opportunities for exchange and investment, and enhanced job opportunities through the emergence of a dynamic labour market that has created increased demand for both unskilled and skilled workers in rural areas and the growing urban centres. The role of development partners in rice introduction in the early 1970s and later through the support in rice R\&D efforts also played an important role in the growth of the rice sector.

The business opportunities rice offered to small-scale private actors was also crucial in the expansion of rice as a commercial crop, not only in Fogera, but in other parts of Ethiopia. For instance, the expansion of rice production in the Guraferda area in SNNPR, which is now one of the fastest growing rice producing areas in the country, was made possible by a private initiative of smallholder farmers and processors who tested and adopted rice production and processing methods observed in other regions (Workye, Goshu and Tegegne, 2019).

Despite clear improvements in living standards and food security for many households engaged in rice commercialisation in Fogera, however, not all households have benefitted equally. As has been shown, multiple livelihood strategies and trajectories exist at the same time in the same places and create an agrarian dynamic that has a broader effect on social relations, politics and the rural economy. As accumulation occurs among some individuals and farming households, so too does social and economic differentiation, creating both 'winners' and 'Iosers'. This dynamic is likely to continue and possibly even accelerate as certain households 'step up', 'step out' or 'step in' to rice-based commercial activities both on and off farm, driving investment, innovation and accumulation, on the one hand, and increasing social differentiation and even displacement on the other.

Furthermore, it must be stressed that success in the expansion and increase in rice production and commercialisation in Fogera and the other emerging rice growing regions, while impressive in many respects, remains modest in scale. Consequently, the pace of increased domestic production is still considerably slower than consumption rates, which continue to rise steeply. This has forced Ethiopia to import large volumes of rice from South and Southeast Asia, accounting for 76 per cent of total consumption in 2019 and acting as a major drain on its foreign currency reserves. The key challenges in addressing this supply-demand gap are the low productivity of domestic rice producers, the limited opportunities and incentives for rice processors to invest in improved technology and practices to increase quality, and the poor quality and relevance of public services provided (Assaye and Alemu, 2020).

The role of rice processors in value addition and marketing (of both paddy and milled rice) was found to be crucial in the transformation of Fogera. However, their operation in terms of the type of processing technology used, the skill and expertise of those engaged in rice milling, the availability and extent of use of other facilities (grading, drying, store, required space, etc.), and marketing behaviour indicates significant challenges. This demands: (i) increased professionalisation of rice processing by providing formal training for the operation and maintenance of rice processing facilities, (ii) standardisation of the key requirements for licensing a rice mill and incentivising processors (i.e. through the provision of land with a reduced lease, soft loans or tax holidays) to fulfil quality standard requirements which would require them to invest in key facilities, and (iii) promotion of an improved paddy and milled rice marketing system, with the possibility of incorporating rice in the Ethiopian commodity exchange trading platform.

The enhanced rice commercialisation and its spill-over effects in promoting urbanisation have contributed to the improvement of social inclusion both directly and indirectly. The emerging opportunities include: (i) the direct engagement in rice production as a result of public 
land allocation measures for landless youth families;

(ii) casual and permanent employment opportunities created to support the different rice farm operations at smallholder rice farms, as well as the different activities at rice processing facilities; and (iii) job opportunities created by the different emerging businesses from the spill-over effects of rice commercialisation, including hospitality and tourism, banking, fuel stations, other processing industries, and smaller businesses. The emergence and expansion of small businesses mainly managed by women, like restaurants, coffee houses, and kiosks, has contributed tremendously to empowering women to earn their own livelihoods and creating job opportunities for others.

While it is clear that very significant barriers remain, the observed changes in agrarian relations linked with the increase in rice production and commercialisation in Fogera has highlighted how quickly a farming system can change, turning what was once a food deficit region into a commercialisation 'hot spot'. It also reveals how this can lead to multiplier effects in both rural areas and adjacent urban centres. Indeed, one of the most impressive changes observed in Fogera has been how rural-urban linkages and on- and off-farm opportunities have been strengthened and expanded by the pursuit of the "white gold" of rice. This is partly explained by the labour-intensive nature of rice production itself, which has stimulated a dynamic labour market. It is also explained by the change in consumer demand for rice, which has facilitated the emergence of an equally vibrant local rice processing and marketing industry. In addition, the growth of the rice sector has attracted a whole new set of public and private service providers, from banking and finance to hospitality, which are enhancing the regional economy.

The Fogera case and the recognition that the country needs to become more self-sufficient in domestic rice production led the Government of Ethiopia to establish a National Rice Stakeholder Platform in 2020 to guide policy and investment. The objective of the platform is to: (i) strengthen coordination and advocacy for rice sector development, (ii) facilitate the provision of policy, managerial and technical advisory services for increasing domestic rice production, (iii) support public-private partnerships for mobilising new resources and increasing investments in rice, and (iv) serve as a forum for stakeholder networking along the rice value chain. Whether the platform can translate lessons from Fogera into larger-scale impacts in Ethiopia's other rice-growing regions remains to be seen, but it is evident that the country views rice as a 'strategic commodity' for transforming livelihoods and improving rural economies. 
Alemu D., Yirga, C., Bekele, A. and Tesfaye, A. (2014). Situation and Outlook of Maize in Ethiopia. Addis Ababa: Ethiopian Institute of Agricultural Research (EIAR).

Alemu, D., Tesfaye, A., Assaye, A., Addis D., Tadesse, T. and Thompson, J. (2018). A Historical Analysis of Rice Commercialisation in Ethiopia: The Case of the Fogera Plain. APRA Working Paper 18. Brighton: Future Agricultures Consortium. Available at: https://opendocs.ids.ac.uk/opendocs/bitstream/handle/20.500.12413/14283/APRA_ WP18_Historical_analysis_of_rice_in_Ethiopia_FINAL.pdf?sequence=4\&isAllowed=y (Accessed: 4 May 2020).

Alemu, D., Assaye, A., Addis D., Tadesse, T., Tesfaye, A., Thompson, J., Sabates-Wheeler, R. and Abera, S. (2019). 'Rice Commercialization and Livelihood Pathways of Farmers' in Fogera Plain' in Tadesse T., Atnaf, M. Alemu, D., Tadesse, T. and Shiratori, K. (eds.) Advances in Rice Research and Development in Ethiopia. Addis Ababa: Ethiopian Institute of Agricultural Research, pp. 251-262.

Astewel, T. (2010). Analysis of Rice Profitability and Marketing Chain: The Case of Fogera Woreda, South Gonder Zone, Amhara National Regional State, Ethiopia. An M.Sc Thesis Presented to the School of Graduate Studies of Haramaya University.

Asmelash, Y. (2014). 'Determinants of Adoption of Upland Rice Varieties in Fogera District, South Gondar, Ethiopia', Journal of Agricultural Extension and Rural Development 8(12): 332-38.

Assaye, A. and Alemu, D. (2020). Enhancing Production of Quality Rice in Ethiopia: Dis/incentives for Rice Processors. APRA Brief 22. Brighton: Future Agricultures Consortium. Available at: https://opendocs.ids.ac.uk/ opendocs/handle/20.500.12413/16700 (Accessed: 4 May 2020).

Bekur (1997). 'Rice Production at the Fogera Plain', Magazine of the Amhara National Region State Culture, Newsletter No-3, Tourism and Information Bureau (Amharic Version), Bahir Dar

Berhanu, K. and Poulton, C. (2014). 'The Political Economy of Agricultural Extension Policy in Ethiopia: Economic Growth and Political Control', Development Policy Review 32(S2): s197-s213.

Bezu, S. and Holden, S. (2014). 'Demand for Second-Stage Land Certification in Ethiopia: Evidence from Household Panel Data', Land Use Policy 41: 193-205.

Borras, M.S. (2003a). 'Agrarian Change and Peasant Studies: Changes, Continuities and Challenges - An Introduction', The Journal of Peasant Studies 36(1): 5-3.

Borras, M.S. (2003b). 'Questioning Market-Led Agrarian Reform: Experiences from Brazil, Colombia and South Africa', Journal of Agrarian Change 3(3): 367-397.

Chirwa, E. and Dorward, A. (2016). Agricultural Input Subsidies: The Recent Malawi Experience. Oxford: Oxford University Press.

Clay, J.W. and Holcomb, B.K. (1986). Politics and the Ethiopian Famine 1984-1985. Cultural Survival Report 20. Cambridge: Cultural Survival.

de Waal, A. (1991). Evil Days: Thirty Years of War and Famine in Ethiopia. New York \& London: Human Rights Watch.

Deininger K., Jin, S., Adenew, B., Gebre-Selassie, S. and Demeke, M. (2003). Market and Nonmarket Transfers of Land in Ethiopia: Implications for Efficiency, Equity, and Nonfarm Development. Policy Research Working Paper 2992. Rural Development, Development Research Group. Washington DC: The World Bank. 
Deininger K., Zevenbergen, J., and Ayalew, A.D. (2006). Assessing the Certification Process of Ethiopia's Rural Lands. Presented at the Colloque international "Les frontières de la question foncière - At the frontier of land issues", Montpellier, France, 2006.

Deininger, K., Ali, D. and Alemu, T. (2011). 'Impacts of Land Certification on Tenure Security Investment, and Land Market Participation: Evidence from Ethiopia', Land Economics 87(2): 312-334.

Deininger, K., Ali, D., Holden, S.T. and Zevenbergen, J. (2008). Rural Land Certification in Ethiopia: Process, Initial Impact, and Implications for Other African Countries. World Development 36 (10): 1786-1812.

Devereux, S. and Sabates-Wheeler, R. (2015). 'Graduating from Social Protection?', IDS Bulletin 46(2): 1-12. Available at: https://bulletin.ids.ac.uk/index.php/idsbo/issue/view/13 (Accessed: 20 April 2020).

Dorward, A., Anderson, S., Bernal, Y.N., Vera, E.S., Rushton, J., Pattison, J. and Paz, R. (2009). 'Hanging In, Stepping Up and Stepping Out: Livelihood Aspirations and Strategies of the Poor', Development in Practice 19(2): 240-247.

Dorward, A., Sabates Wheeler, R., MacAuslan, I., Penrose-Buckley, C., Kydd, J. and Chirwa, E. (2006). Promoting Agriculture for Social Protection or Social Protection for Agriculture. FAC Discussion Paper 4. Brighton: Future Agricultures Consortium. Available at: https://assets.publishing.service.gov.uk/ media/57a08c2f40f0b652dd00117e/SP_Growth_Final.pdf (Accessed: 15 May 2020).

EARO (2000). Strategies and Priorities for Rice Research. Addis Ababa: Ethiopian Agricultural Research Organization (EARO)

ERCA (2020) Import Data 2008-2019. Unpublished raw data. Addis Ababa: Ethiopian Revenue and Customs Authority. Accessed: 9 June 2020.

Gebey, T., Berhe, K., Hoekstra, D. and Alemu, B. (2012). Rice Value Chain Development in Fogera Woreda Based on the IPMS Experience. Nairobi: International Livestock Research Institute (Available at: https://cgspace.cgiar. org/bitstream/ handle/10568/16850/IPMS_Rice_CaseStudy.pdf?sequence=8 (Accessed: 3 December 2018).

Gill, P. (2010). Famine and Foreigners: Ethiopia Since Live Aid. Oxford: Oxford University Press.

Gilligan, D., Hoddinott, J. and Taffesse, T.S. (2008). The Impact of Ethiopia's Productive Safety Net Programme and its Linkages. IFPRI Discussion Paper 00839. Washington, DC: International Food Policy Research Institute (IFPRI). Available at: https://www.ifpri.org/publication/impact-ethiopia\%E2\%80\%99s-productive-safety-netprogramme-and-its-linkages (Accessed: 29 April 2018).

Grunditz, M. (2015). Is Villagisation an Acceptable Solution? JURM01 Master Thesis. Faculty of Law, Lund University.

Hauge, J. and Chang, H. (2019). 'The Concept of a "Developmental State" in Ethiopia', in Cheru, F. (ed.) The Oxford Handbook of the Ethiopian Economy. Oxford: Oxford University Press.

Huffnagel, H. (1961). Agriculture in Ethiopia. Rome: Food and Agriculture Organization of the United Nations (FAO) Korn, D. (1986). Ethiopia, the United States and the Soviet Union. London: Routledge.

Lewis, J. (2002). 'Agrarian Change and Privatization of Ejido Land in Northern Mexico', Journal of Agrarian Change 2(3): $402-420$.

McCann, J. (2005). Maize and Grace: Africa's Encounter with a New World Crop, 1500-2000. Cambridge: Harvard University Press.

Meron, A. (2016). 'The Contributions and Challenges of Rice Value Chain Development on Livelihood of Smallholder Rice Farmers (In the Case of Ethiopia Driving Growth Entrepreneurship and Trade (EDGET) Project in Fogera and Libokemkem District)', Geography and Environmental Studies, MSc thesis, Addis Ababa University, Available at: http://etd.aau.edu.et/handle/123456789/5635 (Accessed: 3 December 2018)

MoA. (2013). Rural Land Certification and Administration SLM Knowledge Base. Addis Ababa: Ministry of Agriculture. 
MoA. (2018). Crop Variety Register. Issue No. 21. Plant Variety Release, Protection and Seed Quality Control Directorate. Addis Ababa: Ministry of Agriculture.

MoA. (2020). National Rice Development Strategy-II (2020 - 2030). Addis Ababa: Ministry of Agriculture.

MoANR (2016). Crop Variety Register. Issue No. 18. Plant Variety Release, Protection and Seed Quality Control Directorate. Addis Ababa: Ministry of Agriculture and Natural Resources.

Wubne, M. (1991). 'Resettlement and Villagization', in Ofcansky, T.P. and Berry, L. (eds.) A Country Study: Ethiopia. Washington, DC: Library of Congress Federal Research Division.

Omotilewa, O.J., Jayne, T.J., Muyanga, M., Aromolaran, A.B., Liverpool-Tasie, L.S.O., and Awokuse, T. (2021). 'A Revisit of Farm Size and Productivity: Empirical Evidence from a Wide Range of Farm Sizes in Nigeria', World Development 146. https://doi.org/10.1016/j.worlddev.2021.105592.

Persha, L., Greif, A. and Huntington, H. (2017). Assessing the Impact of Second-Level Land Certification in Ethiopia. Prepared for the 2017 World Bank Conference on Land and Poverty, The World Bank, Washington DC, 20-24 March.

Poonam, D. (2014). 'Rice milling', IOSR Journal Engineering 4(5): 2278-8719.

SAA 2000. (2004). SAA 2000 Annual report 2003-04. Addis Ababa: Sasakawa-Global 2000.

Seck, P.A., Touré, A.A., Coulibaly, J.Y., Diagne. A. and Wopereis, M.C.S. (2013). 'Africa's Rice Economy Before and After the 2008 Rice Crisis', in Wopereis, M.C.S., Johnson, D.E., Ahmadi, N., Tollens, E. and Jalloh, A. (eds.) Realizing Africa's Rice Promises: Priorities in Action. Nairobi: CAB International, pp. 24-34.

Sendeku, W. (2005) 'Factors Determining Supply of Rice: A Study in Fogera District of Ethiopia', MSc thesis, Agricultural Economics, Alemaya University. Available at: https:/www.scribd.com/document/329952730/ Wolelaw-SendekuAgri-Econ-2005 (Accessed: 3 December 2018)

SG 2000. (2002). 'Introducing Rice to Ethiopia', in Feeding the Future. Newsletter of the Sasakawa Africa Association. Issue 18. November 2002, pp. 11.

SG 2000. (2015) Promotion of Rice in Tigray Region, Ethiopia: The Contribution of Sasakawa Global 2000. SG2000 Working Paper, No. 05. Addis Ababa: Sasakawa Global 2000.

Shonhe, T., Scoones, I. and Murimbarimba, F. (2020). 'Medium-Scale Commercial Agriculture in Zimbabwe: The Experience of A2 Resettlement Farms', Journal of Modern African Studies 58(4): 601-626.

Tadesse, T., Alemu, D. and Assaye, A. (2020). The White Gold of Wereta: A City Raised on Rice. APRA Brief 24. Brighton: Future Agricultures Consortium. Available at: https://opendocs.ids.ac.uk/opendocs/ handle/20.500.12413/16702 (Accessed: 30 April 2020).

Tadesse, T., Atnaf, M., Alemu, D., Tadesse, T. and Shiratori, K. (eds.) (2019). Advances in Rice Research and Development in Ethiopia. Addis Ababa: Ethiopian Institute of Agricultural Research.

Tsikata, D. (2015). The Social Relations of Agrarian Change. IIED Working Paper. London: International Institute for Environment and Development.

Watt, I. (1988). 'Regional Patterns of Cereal Production and Consumption', in Zein, A.Z. and Kloos, H. (eds.) The Ecology of Health and Disease in Ethiopia. Addis Ababa: Ministry of Health, pp. 94-134.

Wise, R.D. and Veltmeyer, H. (2016). Agrarian Change, Migration and Development. Agrarian Change and Peasant Studies Series. London: Practical Action Publishing.

Wopereis M., Diagne, A., Johnson, D.E. and Seck, P.A. (2013). 'Realizing Africa's Rice Promise: Priorities for Action', in: Wopereis, M.C.S., Johnson, D.E., Ahmadi, N., Tollens, E. and Jalloh, A. (eds.) Realizing Africa's Rice Promises. Nairobi: CAB International, pp. 424-436. 
Workye, A., Goshu, D., and Tegegne, B. (2019). 'Analysis of Factors Influencing Market Supply of Rice by Smallholder Farmers in Guraferda District, Southwest Ethiopia', Agriculture, Forestry and Fisheries 8(5): 95-99.

Yaro, J.A., Teye, J.K. and Torvikey, G.D. (2017). 'Agricultural Commercialisation Models, Agrarian Dynamics and Local Development in Ghana', The Journal of Peasant Studies 44(3): 538-554. 
Alemu, D., Thompson, J. and Assaye, A. (2021) Rice Commercialisation, Agrarian Change and Livelihood Trajectories: Transformations on the Fogera Plain of Ethiopia, APRA Working Paper 61, Brighton: Future Agricultures Consortium

\section{(cc) BY-NC-ND}

This is an Open Access report distributed under the terms of the Attribution-Non Commercial-No Derivs 4.0 Unported (CC BY-NC-ND 4.0) Attribution - You must give appropriate credit, provide a link to the license, and indicate if changes were made. You may do so in any reasonable manner, but not in any way that suggests the licensor endorses you or your use. NonCommercial — You may not use the material for commercial purposes. NoDerivatives - If you remix, transform, or build upon the material, you may not distribute the modified material. You are free to: Share - copy and redistribute the material in any medium or format.

https://creativecommons.org/licenses/by-nc-nd/4.0/legalcode

If you use the work, we ask that you reference the APRA website (www.future-agricultures.org/apra/) and send a copy of the work or a link to its use online to the following address for our archive: APRA, Future Agricultures Consortium, University of Sussex, Brighton BN1 9RE, UK (apra@ids.ac.uk)

All APRA Working Papers go through a review process before publication.

\section{Cc) creative}

\section{DO YOU HAVE COMMENTS ON THIS PAPER?}

We would welcome your feedback on this working paper!

To provide brief comments, please follow this link to our short APRA Working Paper Feedback form: https://goo.gl/forms/1iVnXhhrlGesfR9

Agricultural Policy Research in Africa (APRA) is a programme of the Future Agricultures Consortium (FAC) which is

generating new evidence and policy-relevant insights on more inclusive pathways to agricultural commercialisation in sub-Saharan Africa. APRA is funded with UK aid from the UK Foreign, Commonwealth \&

Development Office (FCDO) and will run from 2016-2022.

The APRA Directorate is based at the Institute of Development Studies (IDS), UK (www.ids.ac.uk), with regional hubs at the Centre for African Bio-Entrepreneurship (CABE), Kenya, the Institute for Poverty, Land and Agrarian Studies (PLAAS), South Africa, and the University of Ghana, Legon. It builds on more than a decade of research and policy engagement work by the Future Agricultures Consortium (www.future-agricultures.org) and involves more than 100 researchers and communications professionals in Africa, UK, Sweden and USA. 